\title{
Shirodhara healing - an ultimate Ayurvedic holistic remedy
}

\section{Opinion}

To many, Shirodhara (Chakra Healing) is simply an unbroken stream of oil impinging on the forehead.... Oil being poured over ones forehead while lying in a relaxed position. But is that all this oldest living healing therapy entails?

Such an image presents a very limited view of Yoga/Ayurvedic healing. Very few people realise that Shirodhara (Chakra Healing) is a highly specialized and scientific from ancient healing that flush out all garbage from mind and body/resulting one to feel gravity free.

The whole process of Shirodhara (Chakra Healing) is the awakening of intelligence on the cellular level. Self-awareness is about observing yourself and recognizing the feeling as it happens inside and outside. This is the first step towards perfect health which we are longing for and we deserve. It is all about intelligence.

There has been a lot of discussion about intelligence. Is knowledge intelligence? Is skill intelligence?

In Yoga/Ayurvedic we consider mainly two types of intelligence - SWABHAVIK (innate Intelligence) and MANUS (cognitive intelligence). Cognitive intelligence derives from our education. It is what we learn. And it involves many categories.

Moral intelligence is the ability to distinguish between right and wrong. Social intelligence is the ability to understand other people around us. Emotional intelligence is a skill that helps people harmonise. We learn to manage emotions appropriately learning what lies behind a feeling, finding ways to handle fear and anxiety, anger and sadness. We learn to channel emotions in the service of a goal exercising emotional self-control, delaying gratification and stifling impulses. In showing empathy, we display a sensitivity to others feelings and concerns - taking their prospective.

In handling relationships we endure to understand others emotions, thus developing social competence and skills.

Spiritual intelligence is a relatively new concept which is not necessary related to religion. Spiritual intelligence is about the human need and talent for finding meaning in experiences. It is our access to and use of meaning, vision and value in the way, we think and the decision we make. Above all is environmental intelligence, which is essentially communal intelligence.

As per Yoga/Ayurvedic, most of these cognitive intelligences are washed away at the time of death and only a few carry over to the next life to become part of SAWABHA innate intelligence. Innate intelligence can be demonstrate by a cow finding its mothers teats within minutes.

All of us are born with this SWABHAVIK Innate Intelligence. It is important to remember this as it brings with it the means towards complete self-healing.

The process of Yoga/Ayurvedic is to awaken our cellular intelligence. It is not only about our strength, but also our weaknesses.
Volume I Issue 4 - 2015

\author{
Ram Garg \\ Kurukshetra University, India
}

Correspondence: Prasad S Koka, Department of Virology and Immunology, Haffkine Institute, Acharya Donde Marg, Parel, Mumbai, Maharashtra 4000 I2, India, Tel 91 99000469I0, Email ram_ayurveda@yahoo.com

Received: August 13, 2015 | Published: August 24, 2015

Every cell, every organ knows its limitation by default, what it is capable of and what it is not. Cellular intelligence brings about total harmony inside and outside. It is time tested fact that the process of disease starts in aura (conscious networking) of a human being. Illness is nothing but disturbance of this innate intelligence. There are different causes for this - some of which include bio spiritual consciousness. There are also many diseases that impact on physical and mental health.

The process of impaired awareness begins in the unconscious mind and we engage our self in incorrect life patterns. Slowly TAMASIC FORCES (bad spirits, bacteria, or viruses) take over our activities. Initially we cannot see the effects and causes and we only become aware of these subjective symptoms once our vital organs are effected.

For example we feel some alarming symptoms, lack of energy, mood swings and sleep disturbances, but we tend to ignore these in favour of our robotic lifestyle. I agree that consumption of contaminate sensitive food as well as our world of digitization and our dependence on it, is the truth and reality of our life today. We cannot, and must not ignore this fact for any reason. At the least we must find a balance between our work and our being. The answer is not a quick fix from pharmacy counters or a gym or a healer. The answer lies in working around the impact of the system within us.

Furthermore, we must understand that with conventional approach, anything that is overcome has to be conquered again and again. No problem can be finally overcome or conquered. The issue can be understood, but not conquered. We can try to resist, dominate or do battle with the problem, or we can build a defense against it. But we will create further conflict.

Alternatively we can understand our fears, go into it fully, step by step and explore the whole content of it, in which case the problem will never return in any form. That is what Yoga/Ayurveda is all about.

Ayurvedic Shirodhara (Chakra Healing) is not only beneficial to people who are ill or suffer from bad health. It also benefits people with healthy disposition byassisting them tomaintain wellbeing andwellness. 
The main effect of Shirodhara (Chakra Healing) is on 6th Chakra (Agya Chakra). This is the junction between personal consciousness and collective consciousness.

Shirodhara (Chakra Healing) helps to take charge of our health with improved cellular intelligence. Kundalini energy is one of the main connections between the nervous system and the hormonal system. It controls body temperature, hunger, thirst, water balance and the sexual functions and also the metabolic function in general It is also relative to emotions and sleep, and governs all of this by regulating the automatic functioning of the nervous system through the hormones.

What is this all powerful force that brings joy or sorrow so quickly? Well actually no one knows. Even in the scientific community, there is a great honesty about the actual lack of understanding of most of these Nero- hormonal functions. Although much is known, much is still mysterious. This 6th Chakra controls these hormonal secretions by receiving information from the brain cells and also from endocrinal system via a complex negative feedback mechanism.

Yoga/Ayurveda considers that one major functions of Kundalini is to link the physical and subtle bodies Ayurvedically a human being is to halves joined together. We are made up of two poles - Shiva (positive) and Shakti (negative). There should be always a balance between these two poles. This is controlled by a point between the third eye and the back of scull. We call it Agya chakra which controls most of our functions during our life span.

During Shirodhara (Chakra Healing), the brain releases specific biochemical stuff. It acts like a chemical messenger that heals body and spirit. The ancient yogi's were not mere dreamers of cosmic consciousness, where our bodies, our brain and its mind, are inextricably joined with other matter and the mega dipole of the universe. Old Indian sages realised that Shirodhara (Chakra Healing) can wipe mistake off the DNA blueprint and destroy any disease that has disturbed the natural design. Besides physical cleaning and rejuvenation the release of mental demons - like fear, jealousy, anxiety, excessive thinking, phobias, insomnia, schizophrenia, obsessive compulsive disorder like hoarding, guilt, lack of self-worth, ego, hysteria, mood swings addictions inability to unlearn etc. Shirodhara (Chakra Healing) reprograms all these. In short, people who have one leg in the past and one leg in the future need to focus in the present moment. When the mind returns to its level of consciousness, it acquired some freedom to move. Grace and peace are the hallmark of a healthy, non-delusional mind in a healthy body. In that state happiness is stable as it becomes nature.

Music provides a healthy version of sound-vibration which helps to remove illnesses and engender a healthy spirit, mind \& body. Every sound carries with it some content of words, vibrations, tone, rhythms, tunes, pitches and certain intensities of the frequency. The mantra of music makes particular impact on a living being. They are helpful in correcting the disarranged rhythms of body as well as mind. Because humans enjoy rhythmic contents of heartbeat, lung function and intestinal movements as well as the function of each and every call and tissue and the mind, the vibrations of music have a profound effect on sub consciousness mind, which in turn reorganizes and tones up the normal rhythm of the body organs.

Indian music embraces RAGAS (Instrumental), ALAPS (Vocal), VANI (speech), the sound vibrations and the human vibrations harmonise and provide a healthy resonance in mind and body. Specific sounds elicit specific emotions or toxins which impact different cells.
Shirodhara (Chakra Healing) is not only healing. It elicits energy, kindness, compassion. Together with music it provides perfect health.

There is no description of Shirodhara (Chakra Healing) in ancient Yoga/Ayurveda scriptures. It was introduced by Sage Nagarjuna in the second century B.C. The probable case was for seedy results and also to combat fear and uncertainty caused by intruders to the Indian sub-continent.

I use this treatment widely all over the world with fairly good results. I have developed my own way of dealing with different who exhibit different problems. Only when I meet with a patient do I select the oils and music according to his/her needs. This Ayurvedic process brings about a new interpretation of the understanding between doctor and patient.

Being a qualified Yoga/Ayurveda doctor I not only examine the physical body, but take down and extensive personal and medical history, including questions about daily diet, profession and working condition, exercise, routines, relationships and mental health. This thorough process helps me to identify key symptoms and potential causes of sickness.

Most of us are familiar with visiting a health care provider when we feel ill. The provider diagnosis the sickness and determines what has caused it. The treatment is then geared towards selecting a technique to battle the pathogens. Invariably the same medicine, procedure and doses are used for all those battling the same illness. By comparison Ayurvedic diagnosis and subsequent treatments differ from this western process in that the diagnosis is made not only on the disease level (called ROGA) but also on the patient level (called ROGI) this exhaustive examination helps the Ayurvedic doctor to not only diagnose the disorder, but individualize and tailor treatment for each patient.

The Ayurvedic doctor considers the whole human being, believing that people have within them the required energy to bring the body back to a healthy or balanced state. So instead of focusing on a treatment or medicines to heal the illness the Ayurvedic doctor concentrates on the technique that will strengthen the healthy elements inherent in everybody that will intern help the individual to recover. The tent is called SVABHAVOPARAMAVADA, which refers to the Ayurvedic ideal of helping the body call upon its own energy to heal. Treatments and medicines are a vital part of this process. But only act to support the body self-reparation, rather than cause it.

There are two very important parts of this unique healing process the selection of the oil and the music. Different people have different needs so doctor deliberated the oil to be used and the appropriate sounds. Before I tell you about the third eye, I would like to tell you about two events. It will make things easier for you to understand. Both of them are historically factual.

In 1888 a person named Ramanujan was born in a poor Brahman family in South India. He became a very famous mathematician. He was not able to study much, but still his genius in mathematics was unique. He has no training or guidance from anyone. With great difficulty he got a clerical job, but very soon news spread that he had a hidden emerging talent in mathematics. Someone suggested that he write a letter to the famous mathematician professor Hardy of Cambridge University who was the most immanent mathematician in those days. He did not write a letter, but solved two theorems of geometry and send them to Professor Hardy. Hardy was astonished to receive these and could not believe that someone so young could solve 
such theorems. He immediately wrote back to Ramanujan and invited him back to England. When Hardy met him for the first time, he felt that he was like a child before Ramanujan in the field of mathematics. The genius and the capabilities of Ramanujan were such that they could not be due to mental powers because the intellect moves very slowly, thinking takes time but Ramanujan did not take any time in responding to Hardy's questions. No sooner was the problem writing down on the blackboard or put to him verbally then Ramanujan began to rely without any time gap to respond. It was very difficult for great mathematician to understand how it happened. A problem which should have taken 6 hours Ramanujan solved instantaneously, unerringly.

It proved that Ramanujan was not replying through the medium of mind. Even though he was not very learned and there was no other sign of intellectual ability but in mathematics he was super human. He die when he was 36 because of tuberculosis. When he was in hospital, Hardy, along with two or three other mathematician friends went to see him. When Hardy went into his room, he told Hardy that his number plate was unique. It had four special aspects to it. After that, Ramanujan died. Hardy took 6 months to understand what Ramanujan understood, but he could only discover three of the four aspects. 22 years after Hardy death, the fourth was discovered, Ramanujan was right.

Whenever he began to look into any mathematical problem something began to happen in the middle space between his two eyebrows. Both hi eyeballs turned upwards centering on the middle space in Yoga/Ayurveda this space is described as the 3 eye spot because when it is activated it is possible to see the events and scenes of different world in their entirety. It is like looking out of your house through a small hole in the door and suddenly when the door opens you see the whole sky. Ramanujan eyes rose to his third eye when solving a problem. No one could understand this Ayurvedic phenomenon nor could any other western mathematician even understand it in the future.

I will tell another event so you will be able to understand its relationship to the third eye. Edgar Cayce die in 1945. In 1905 he fell sick, became unconscious and remained in a coma for three days. The doctor had lost all hope and said he could not bring him back to consciousness. They thought that his unconsciousness was so deep that perhaps he would never come out of it. All medicines were tried, but there was no sign of his regaining consciousness. On the evening of third day Cayce suddenly started speaking even though he was in a coma. He said that he has fallen from a tree, his backbone is injured. He also said that he need some herbs. He suggested some herbal medicines that should be given to drink then he would recover. The names of the herbs which he requested were not likely to have been known to Edgar Cayce. First doctor did not take him seriously, but because Cayce had specifically mentioned them they thought they should try them. Those substances were searched for and given to Cayce and he recovered fully within 12 hours.

After he became conscious Cayce could not remember suggestions such medicines neither could he remember this incidence. But this event in Cayce was beginning of a rare happening. He became an expert in suggesting medicines for incurable disease. He cured about 30000 people during his life. Every patient was cured. But Cayce himself was not able to explain it. He could only say that whenever he closed his eyes to look for some treatment, both his eyes turned upwards as it turned towards the middle of these two eyebrows. He eyes became fixed there and he forgot everything. Only in that state would the recommended treatment come to him. Two of his remedies are worth recording. The Rothschilds were a very rich family in America. A sick woman from his family was brought to Cayce. He suggested a particular medicines. Rothschilds searched throughout America without success. After three weeks a man from Sweden wrote that his father had patented a medicine of that name but had never manufactured it. He sends the formula. The medicine was sent to the woman and she recovered well. How could Cayce known of a drug that was not even available in the market?

In another incident Cayce suggested a specific medicine which could not be found. A year later a newspaper announced the availability of that medicine. In other words while the medicines suggested were tested in the laboratories and did not carry a name Cayce had known about it. The medicine was given to the patient who soon recovered. What do we call this state of Edgar Cayce? We have to call this state unconscious, but those Ayurvedic Seers who knows about this mysterious happening they would say he was fully conscious at that time. In fact unconsciousness continues until our knowledge reaches the third eye.

In Yoga/Ayurveda, this third eye functions are in the same way as a patient's progress chart in the hospital does for the doctor. The nurse goes on recording temperature, BP and Pulse. The doctor just needs to see the chart to see the condition of patient. Similarly in Yoga/ Ayurveda the third eye is able to indicate the condition of a person. A Yoga/Ayurveda doctor is able to assess the changes needed, diagnosis, and provide therapeutic remedy.

One another aspect of third eye is that it is the very center of will power. In Yoga/Ayurveda and yoga we call it agya chakra because whatever we have in our life is governed by it. Whatever order and harmony there is in our life arises from this point. As soon as this center of will power becomes active, the mind-body -duo stops giving orders and instead they start to obey; the whole mismanagement is reversed. Many experiments have been performed in Yoga/Ayurveda to awaken this center. As soon as the third eye is activated, it separates the sufferings.

After hundreds of experiments in the past and now using, Shirodhara (Chakra Healing), many oils have been selected. A sort of resonance is established between oil and the sensitivity of third eye. So as the oil is poured on that particular spot, they deepen its sensitivity. When Shirodhara (Chakra Healing) treatment is applied on the right spot with right stuff, the process/ outcome is very deep.

Shirodhara (Chakra Healing) is the king of all healing modalities. In the sense it provides basic surgery of unconscious mind and amputates negativity so as to expand consciousness.

Friend, the advent of drugs came much later, but the earliest cure for disease was found in nature. Now once again the pendulum is swinging back towards traditional remedies. One thing that I must set straight while that natural remedies have an obvious appeal, they may not cure some conditions. However they definitely reduce dependency on drugs and can invariably help you to avoid them. You'll have agreed it takes more than a prescription pad to really bring relief, peace and happiness. Fortunately the Yoga/Ayurveda healing energy has known and practiced in Indian sub-continent for centuries and passed on from generation to generation. 
I have an integral approach to health and work very closely with my patients to find unique solution to their presenting symptoms, and drawing on a variety of ayurvedic techniques. We have two Yoga/ Ayurveda center located in Johannesburg, South Africa and Rishikesh, North India. Diagnosis and treatment is offered at our both center, while Rishikesh center also offer Panchkarma, yoga, mediations, 4 star lodging, Yoga/Ayurveda cooking, healing classes, tourists attractions and much more.

Besides this, we organize clinic in different part of world on regular basis. In my opinion Shirodhara (Chakra Healing) is not only curative remedy but also a wonderful preventative management like rebooting your system or servicing car 3-4 times a year. Friends I have written this newsletter as best of my capabilities and knowledge. Your kind suggestions will be highly appreciated.

\section{Acknowledgments}

None.

\section{Conflict of interest}

The authors declare that there is no conflict of interest.

\section{Funding}

None. 